Grzegorz Szamocki

University of Gdańsk

grzegorz.szamocki@ug.edu.pl

ORCID: 0000-0002-8586-8284

DOI: http://dx.doi.org/10.12775/BPTH.2019.027
Biblica

et

Patristica

Thoruniensia

12 (2019) 4: 513-530

ISSN (print) $1689-5150$

ISSN (online) 2450-7059

\title{
"YHWH Came from Sinai" (Deut 33:2). The Motif of the Mountain in the Context of the Pentateuch Redaction*
}

\author{
„JHWH przyszedł z Synaju" (Pwt 33,2). \\ Motyw góry w kontekście redakcji Pięcioksięgu
}

\begin{abstract}
The mention of the coming of YHWH from Sinai in Deut 33:2 can be considered a literary production of the final redaction of the Pentateuch. The editor, in the elaboration of the ending of the Pentateuch, emphasizes what is to be a mainstay for the sons of Jacob: a relationship with God who appeared in Sinai, as well as an awareness of holiness and the possession of the Law.

Some statements in texts intertextually related suggest that emphasizing YHWH's relationship with the mountain served to indicate his uniqueness and thus the otherness and distinctiveness of Jacob's sons from other nations.

The emphasis on YHWH's relationship with the mountain in the Deuteronomy framework text (33:2-5) reflects the nature and ideas behind the pentateuchal redaction. The more universalized concept of the identity of $\mathrm{YHWH}$ and Israel can be seen in some of the statements attributed to the editors of the Hexateuch.
\end{abstract}

Streszczenie. Wzmianka o przychodzeniu JHWH z Synaju w Pwt 33,2 może być uznana za literacki element końcowej redakcji Pięcioksięgu. Redaktor, w opracowaniu zakończenia swego dzieła, podkreśla to, co ma stanowić ostoję dla synów Jakuba: związek z Bogiem, który objawił się na Synaju, oraz świadomość świętości i posiadania Prawa. Niektóre wypowiedzi we fragmentach powiązanych intertekstualnie sugerują, że podkreślanie związku JHWH z górą służyło wskazaniu na Jego wyjątkowość i tym samym na inność i odrębność synów Jakuba od innych narodów.

Wyakcentowanie związku YHWH z górą w tekście ramowym Księgi Powtórzonego Prawa (33:2-5) odzwierciedla naturę i idee przyświecające redakcji Pięcioksięgu. Bardziej zuniwersalizowaną koncepcję tożsamości JHWH i Izraela można dostrzec w niektórych wypowiedziach przypisywanych redakcji Heksateuchu.

This article is part of a research project financed by the National Science Centre, Poland (No. 2018/29/B/HS1/01203). 
Keywords: Mountain; Sinai; incomparability; identity; Deuteronomy; pentateuchal redaction.

Słowa kluczowe: Góra; Synaj; nieporównywalność; tożsamość; Księga Powtórzonego Prawa; redakcja Pięcioksięgu.

\section{Introduction}

According to Deuteronomy, the last words of Moses, just before his death, were the words of a blessing given to the Israelites (Deut 33). The corps with the blessings of the individual tribes of Israel (33:6-25) are framed by a hymnic introduction (Deut 33:2-5) and ending (33:26-29). The introduction begins with the statement of the relationship of God JHWH with Mount Sinai, expressed in the words: "YHWH came from Sinai". Why is the mountain of YHWH's theophany and his covenant with the Israelites called "Sinai" only in this place in Deuteronomy, while it is mentioned 9 times as "Horeb"? What is the significance of recalling Sinai right here? The purpose of this article is to try to answer these questions.

\section{Deut $33: 2$ as a testimony of the final redaction of the Pentateuch}

In the actual text of Deuteronomy, the blessings of Moses (Deut 33) are located before the mention of his death and burial in Deut 34, and after the Song of Moses in Deut 32:1-43 that could already end his great speech in Deuteronomy, because it is followed by Moses' final exhortation to observe the teaching given (Deut 32:44-47) and YHWH's command that Moses go up to Mount Nebo, which will be the place of his death (Deut 32:48-52).

The first sentence of chapter 33, with Moses' farewell blessings of Israel, serves as the title: "This is the blessing that Moses, man of God, pronounced over the Israelites before he died" (v. 1). It is followed by the words of Moses, in which the three parts mentioned above are distinguished: the introduction (v. 2-5), the blessings of the individual tribes (v. 6-25) and the ending (v. 2629). The introduction and ending have a form of two related stanzas of a hymn (v. 2-5.26-29). The first stanza (Deut 33:2-5) begins with the statement about the theophany of God JHWH (v. 2a), with the opening phrase: "YHWH came from Sinai". At the end, there is a mention of the kingship of YHWH in Jeshurun, when the tribes of Israel were gathered (v. 5). While in the centre are words praising God for his universal kingship (v. 3). They are framed by the mention of the Law of JHWH, which the gathered community received through Moses (v. 2b.4). So, in the first stanza one can see a chiastic structure. 
${ }^{2}$ YHWH came from Sinai,

Rose from Seir to them.

He shined forth from Mount Paran,

and he came from the ten thousands of holy ones.

At his right hand was a fiery law for them.

${ }^{3}$ Yes, he loves the people;

All his saints are in your hand:

They sat down at your feet;

Everyone shall receive of your words.

${ }^{4}$ Moses commanded us a law,

An inheritance for the assembly of Jacob.

${ }^{5}$ He was king in Jeshurun,

When the heads of the people were gathered,

All the tribes of Israel together.

The second stanza of the hymn (v. 26-29) contains first the statement of the uniqueness and incomparability of God JHWH ("there is none like the God of Jeshurun") with a brief explanation (v. 26-27a), and then the statement of Israel's uniqueness and incomparability, also with a brief explanation (v. 29a) and an unfolding of it and indication of the consequences of such Israel's status (v. 27b-28.29b).

${ }^{26}$ There is none like God, Jeshurun,

Who rides on the heavens for your help,

in his excellency on the skies.

${ }^{27}$ The eternal God is your dwelling-place,

Underneath are the everlasting arms.

He thrust out the enemy from before you,

Said, Destroy.

${ }^{28}$ Israel dwells in safety,

The fountain of Jacob alone,

In a land of grain and new wine;

Yes, his heavens drop down dew.

${ }^{29}$ Happy are you, Israel: Who is like you,

a people saved by $\mathrm{YHWH}$,

The shield of your help,

The sword of your excellency!

Your enemies shall submit themselves to you;

You shall tread on their high places. 
Both stanzas are connected by words and motifs. Three names are significant in this respect, namely: "Jeshurun" (v. 5.26), "Jacob" (v. 4.28) and "YHWH" (v. 2.29). The chiastical order of these names (v. 2.4.5 || 26.28.29) underlines the coherence of the framing text. ${ }^{1}$

While the opinion of scholars from the beginning of critical research was broadly consistent regarding the distinction in Deut 33 of those three parts (33:2-5.6-25.26-29), dating the text of this chapter appears to be more difficult and hence there have been and are various attempts and concepts of understanding and explaining this issue. The analyzes carried out have led some exegetes to the conclusion that the formation of the entire text of Deut 33 should be associated with the pre-state or early monarchical period of Israel's history. ${ }^{2}$ Others researchers, especially the authors of earlier studies, pointed frequently to the eighth century ${ }^{3}$, although there were also voices that the hymnic framework in Deut 33:2-5.26-29 is a postexilic additive. ${ }^{4}$ Already in studies from the turn of the century $\left(19^{\text {th }} / 20^{\text {th }}\right)$, Gen 49 with the blessing of Jacob was recognized as a pattern for the blessing of Moses in Deut 33, and the inclusion of Deut 33 in Deuteronomy was attributed to the final redaction of Pentateuch. ${ }^{5}$

In one of the newer suggestions for solving the problem, the thesis was put forward according to which a Deuteronomistic collector (Sammler) in the 6th century BC used and developed the old material (Grundschrift) from the 11th century BC with blessings and an independent hymn, that served as a framework of the tribal senstences. This text would be supplemented in the exilic period by a late Deuteronomistic redactor. ${ }^{6}$

The latest studies links the formation of Deut 33 with the final redaction of Pentateuch and emphasize the dependence of Deut 33 on Gen 49. Noteworthy is the opinion of E. Otto, according to which the text Deut 33:6-25 is the fruit of the post-exilic development (Fortschreibung) of Deuteronomy and was included by the redactor of Pentateuch as a complementary counterpart to Gen

1 About the structure of Deut 33:2-5 see e.g. E. Otto, Deuteronomium 12-34, p. $2221-$ -2223; cf. D.L. Christensen, Deuteronomy 21:10-34:12, p. 834. On the textual and semantic problems of Deut 33:2-5 see especially e.g. S. Beyerle, Der Mosesegen, p. 14-35.

2 So e.g. U. Cassuto, Biblical and Oriental Studies, p. 47-70; F.M. Cross, D.N. Freedman, The Blessing of Moses, p. 191-210; A.H.J. Gunneweg, Über den Sitz im Leben, p. 245-555.

3 E.g. K.H. Graf, Der Segen Mose's, p. 79-82; A. Kuenen, Historisch-kritische Einleitung, p. 227-229; E. Reuss, Die Geschichte der Heiligen Schriften, p. 268-269.

4 So e.g. J. Hempel, Die Schichten des Deuteronomiums, p. 266-267.

5 So e.g. A. Dillmann, Die Bücher Numeri, p. 416; A.F. Puukko, Das Deuteronomium, p. 116; cf. E. Otto, Deuteronomium 12 - 34, p. 2226.

6 So S. Beyerle, Der Mosesegen, p. 275-276. 
49. In this way, the Deuteronomy would be associated with the history of the patriarchs and thus more integrated with the Pentateuch. ${ }^{7}$

In the hymical material in Deut 33:2-5.26-29, which frames the words of the blessings (Deut 33:6-15), some exegetes perceived two stanzas of an originally independent psalm from the pre-monarchical and early-monarchical period of Israel. ${ }^{8}$ However, detailed analyses convince that in the case of this framework text (Deut 33:2-5.26-29), we are confronted with a development geared towards already existing older blessings (Deut 33:6-25). ${ }^{9}$

There are links and references between Deut 33:2-5.26-29 and the - recognized as late-post-exilic - Song of Moses in Deut 32. ${ }^{10}$ The elements connecting these two works are not only words and expressions but also theological aspects, such as for example the effectiveness and incomparability of God YHWH (Deut 32:12.16-17.21.37.39; 33:26) and his reliability in coming with help (Deut 32:38-39; 33:26.29). These intertextual relationships suggest assigning both texts to the same authors, who introduced their works postredactionally to Deuteronomy during its postexilic updatings /development and wanted to connect them with the blessing of Moses. ${ }^{11}$

The text of Deut 33:2, starting with the phrase "YHWH came from Sinai”, presents a poetic description of theophany. As such, it shows similarity to three

7 Some of the statements in Deut 33 clearly indicate a content-based correction in relation to Gen 49. For example, while in Gen 49:5-7 there are words of curse for Simeon and Levi because of the murder of the Shechemites (Gen 34), so in Deut 33:8-11 there is a blessing for Levi but because of the significance of the priests coming from his tribe. In turn, the superiority and importance of Judah emphasized in Gen 49 were limited in Deut 33 in favor of the remaining tribes of Israel. Cf. E. Otto, Deuteronomium 12 - 34, p. 2230-2236 and also e.g. T. Römer, Der Mosesegen, p. 356; H. Pfeiffer, Jahwes Kommen, p. 178-203; H. Pfeiffer, Mosesegen, p. 3-4; M. Leuenberger, Segen und Segenstheologien, p. 345-357.

8 E.g. T.H. Gaster, An Ancient Eulogy, p. 53-62; S. Mowinckel, Der achtundsechzigste Psalm, p. 76-77; P.D. Miller, Two Critical Notes, p. 240-243; J. Jeremias, Das Königtum Gottes, p. 82-92; G. Braulik, Deuteronomium II, p 236-237; A.S. van der Woude, Erwägungen zum Rahmenpsalm, p. 281-288; S. Beyerle, Der Mosesegen, p. 275.

9 Cf. H. Pfeiffer, Jahwes Kommen, p. 193-195; H. Pfeiffer, Mosesegen, p. 5; E. Otto, Deuteronomium 12 - 34, p. 2236-2238.

10 On the subject of Deut 32 dating, see for example: R. Bergey, The Song of Moses, p. 33-54; M. Thiessen, The Form and Function, esp. p. 421-424; T.D. Nilsen, The Origins of Deuteronomy 32.

11 An example of the terminological connection of both texts may be the title Jeshurun for Jacob /Izrael, which in the Hebrew Bible appears only in Deut 32:15; 33:5.26 and in Is 44:2, and the pronominal suffix for 3 masculinum pluralis - mô, which has been used only in Deut 32: 23.27.32 (2x).35.37.38 and Deut 33:2 (2x). Cf. e.g. H. Pfeiffer, Jahwes Kommen, p. 195-197; H. Pfeiffer, Mosesegen, p. 5-6; E. Otto, Deuteronomium 12 - 34, p. 2236-2237. 
other Hebrew Bible texts, namely Judg 5:4-5; Hab 3:3 and Ps 68:8-9. Each of them mentions the coming of YHWH from the south, and the two speak in this context clearly about the Sinai (Judg 5:5; Ps 68:8-9.18). All three appear to be post-exilic. ${ }^{12}$ The conducted research suggests that in Deut 33:2-5.26-29 we are dealing with the reception of their statements. The framework hymnical text can, therefore, be regarded as late-post-exilic (5th/4th century BC) and related to the development of Deuteronomy in the context of the Pentateuch redaction. ${ }^{13}$

\section{Deut 33:2-5.25-29 as a reminder of the foundation of Israel's identity and uniqueness}

Deut 33:2 begins with an epiphanic formulation which gives geographical names as designations of the origin and revelation of $\mathrm{YHWH}$ :

"YHWH came from Sinai, ... he rose from Seir, ... he shined forth from Mount Paran".

The exact location of these places is difficult and still in the sphere of discussion. It is not known whether Sinai lies in the south of the Sinai Peninsula, or in the southeast or southwest of the Gulf of Aqaba. ${ }^{14}$ Seir is the name of

12 However, this is not a common opinion among exegetes. Some scholars prefer earlier dating. See e.g. B. Lindars, Judges 1-5, p. 215; H.-D. Neef, Deboraerzählung und Deboralied, p. 115; S. Mowinckel, Der achtundsechzigste Psalm, p. 76-77; J. Gray, A Cantata, p. $18-19$.

On Judg 5:4 as part of late-post-exilic edition of the Song of Deborah (Judg 5) see e.g. M.Z. Waltisberg, Zum Alter der Sprache, p. 218-232; C. Levin, Das Alter des Deboralieds, p. 124-141 (esp. 133-134.140-141); W. Groß, Richter, p. 305-311; cf. also H. Pfeiffer, Jahwes Kommen, p. 259; T. Mayfield, The Accounts of Deborah, p. 324-325; H.-J. Fabry, Habakuk, Obadja, p. 120-126.299.

On the edition of Ps 68 during the Persian period and about the correlation of Ps 68:8-9 with Judg 5:4-5, as its expanded and reworked version, see e.g. M.E. Tate, Psalms 51-100, p. 174; S. Sussman, Psalm 68, p. 238-240; I. Knohl, Psalm 68, p. 1-21 (esp. 15-20). More on dating of Ps 68 see e.g. G. Ravasi, Il Libro del Salmi, p. 364-367; F.-L. Hossfeld, Psalm 68, p. 250.252-253.

13 So e.g. E. Otto, Deuteronomium 12 - 34, p. 2237-2238. For discussions about the direction of the dependence between Deut 33:2 and Hab 3:3 see also e.g. D. Markl, Hab 3, p. 99-108; H.-J. Fabry, Habakuk, Obadja, p. 120-126.299-301.

14 For various suggestions for the location of Mount Sinai, see e.g. J.K. Hoffmeier, Ancient Israel in Sinai, p. 115-148; S. Jacobovici, Mount Sinai; H. Shanks, Where is Mount Sinai?, p. 30-41. 
a mountainous region southeast of this bay. The location of Mount Paran is also unknown. ${ }^{15}$ It can therefore be assumed that the names given in Deut 33:2 Sinai, Seir and Paran - do not point to specific places where JHWH appeared, but indicate the territory and the direction with which JHWH's theophany was associated. However, if the literary formulation in Deut 33:2 is based not on the historical memory, but on the reception of already given texts (Judg 5:4-5; Hab 3:3; Ps 68:8-9.18), it should not be inferred from Deut 33:2 about the beginnings of the Yahweh religion in the region south of Israel on both sides of Araba, nor that the location of these beginnings in Sinai was due to the impossibility of contact with God in the homeland during the exile. In the words of the hymn about YHWH that came from Sinai, we have rather a testimony of tradition or traditional knowledge about the origin of Israeli religion from the south. ${ }^{16}$ So we may assume that in our text the names Sinai, Seir and Paran communicate the idea of the departure point of YHWH's theophany, whose aim was to come to Israel's help (Deut 33:29). The presence in Deut 33:2 of the name "Sinai” instead of „Horeb” is, however, justified by the reliance of Deut 33:2 on other sources and its subsequent incorporation into the Deuteronomy. The use of the term "Sinai" is firmly anchored in the priestly and post-priestly material of the Sinai pericope (Ex 19 - Num 10). ${ }^{17}$

In the chiastic arrangement of the introductory stanza (Deut 33:2-5) to the blessings of Moses, the statement of YHWH's coming from Sinai, etc. (Deut 33:2) corresponds to the words of his kingship in Jeshurun, where the heads of the people and the tribes of Israel were gathered (Deut 33:5). So, in the hymnical introduction in Deut 33:2-5, YHWH's kingship in Jeshurun is the last act of the theophany of YHWH at Sinai (Deut 33:5). ${ }^{18}$

15 Some scholars identify it with Gebel Munaga in Wadi Feiran in the south of the Sinai Peninsula. So e.g. S Timm, Gott kommt von Teman, p. 210-214. The biblical text, however, clearly says about the mountain (הר) and not about "wadi" - valley (עמק). More see also S. Beyerle, Der Mosesegen, p. 63-65; W. Groß, Richter, p. 307-308; E. Otto, Deuteronomium $12-34$, p. 2239.

16 Cf. and see more e.g. S. Beyerle, Der Mosesegen, p. 66; C. Levin, Das vorstaatliche Israel, p. 149; H. Pfeiffer, Jahwes Kommen, p. 267; M. Leuenberger, Jhwhs Herkunft, p. 1-19 (esp. 11-12); H.-J. Fabry, Habakuk, Obadja, p. 299-301.

17 For differences in the meaning of „Sinai” and „Horeb”, see e.g. L. Perlitt, Sinai und Horeb, p. 302-322; cf. also e.g. W. Oswald, Sinai, p. 1-7; E. Otto, Deuteronomium 12 - 34, p. 2239.

18 „Jeshurun” (ישרון) is the poetic and symbolic name of Israel /Jacob, used only four times in the Hebrew Bible (Deut 32:15; 33:5.26; Isa 44:2). It was derived from the root ישי ("be straight, right") and made, with the diminuitive ending, an honorary title for the people of Israel, highlighting their "upright" ideal character. Some interpreters also sug- 
This kingship of YHWH in Jeshurun, it means over Israel, is rooted in his universal kingship, which is mentioned in the central verse of the first stanza of the hymn (Deut 33:3). Framing this statement by references to the Law (דת, תורה) and to his relationship with Moses, emphasizes the way from the universal kingship of YHWH to his unique kingship in Jeshurun. The title "Jeshurun" might here, therefore, designate Israel as an upright one, in the sense of Law-keeping or upholding justice. In the redaction time of Deuteronomy, in the post-exilic period, it is the honorary title of the addressees of Deuteronomy. ${ }^{19}$

The second stanza of the hymn (Deut 33:26-29), which follows the words of the blessing of the individual tribes (Deut 33:6-25), begins with the statement of the incomparability of YHWH: "There is none like God, Jeshurun”. This incomparability of $\mathrm{YHWH}$ is expressed in his concrete actions for the good of Israel, in coming to help his people and in his sovereignty and excellency (Deut 33:26-27). The hymn presents YHWH using the theophanic motifs known in the ancient Middle Eastern tradition. It says about him: „He rides on the heavens for your help”. In addition, YHWH ist described as „eternal God” (אלהי קדם). As such, he is God since primeval times, who accompanies Israel throughout the whole period of its formation - from creation to the foundation of the Zion sanctuary. ${ }^{20}$ Therefore he can also be its (Israel's) dwelling place or a refuge (Deut 33:27a).

God YHWH, presented in the hymn as coming from Sinai to help Israel, is consequently the foundation of Israel's incomparability with other nations and its uniqueness: "Happy are you, Israel: Who is like you, a people saved by Yahweh, ..." (w. 29a).

It can be concluded that the statement "YHWH came from Sinai" in Deut 33:2 indicates the foundations of Israel's existence and the foundations of its otherness and incomparability with other nations, and thus the foundation of its identity.

gest that Jeshurun could be a term of endearment or a hypocoristicon derived from the

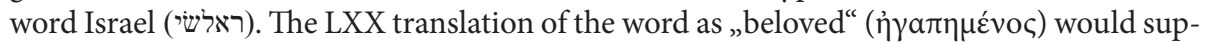
port such a theory. So e.g. G.E. Mendenhall, Jeshurun, p. 868; more see e.g. D.J. Wiseman,

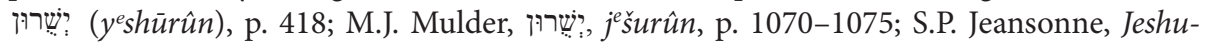
run, p. 771-772; F. Brown, S.R. Driver, C.A. Briggs, The Brown-Driver-Briggs Hebrew and English Lexicon, p. 449; J.L. Koosed, Jeshurun, p. 261; E. Otto, Deuteronomium 12 - 34, p. 2179-2180.2243.

19 Cf. E. Otto, Deuteronomium 12 - 34, p. 2256-2257.

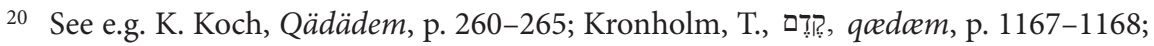
E. Jenni, קדקר, qedem, p. 587-589; C.L. Rogers, קדם (qedem), p. 869; H. Pfeiffer, Mosesegen, p. 5; E. Otto, Deuteronomium 12 - 34, p. 2257-2258. 


\section{Sinai as the foundation of the identity of YHWH's people}

The name "Sinai" occurs in the Hebrew Bible only in reference to Israel's exodus from Egypt and Yahweh's theophany. "Sinai" is the name of the wilderness and the mountain (הר סיני, מדבר סיני, Ex 19:1-2.11.18.20.23), identified with the "mountain of God" (הר האלהים), that was also the place of the call of Moses (Ex 3:1; 4:27). Sinai is therefore presented as the place of the theophany, which led to the deliverance of the Israelites from Egypt, and as the place of the covenant and the receiving of the Law. At Sinai, Israel became a kingdom of priests and a holy nation (מלכת כהנים וגוי קדוש, Ex 19:6). At Sinai, the covenant with God was also broken, by the sin with the golden calf, and then renewed. Sinai, with related events, is therefore the foundation of the religious, legal and political status of Israel and its incomparability with other nations. ${ }^{21}$

For the post-exilic Judean priestly scribes, whose working hands are seen in the narrative about Israel's exodus from Egypt and the theophany at Sinai, this mountain of God - with the desert sanctuary, corresponds to Mount Zion - with the Jerusalem temple. In their concept, Israel gathered at Sinai is an archetype for the post-exilic community at Mount Zion. The reason for such literary activities of the post-exilic priestly scribes could have been the desire to indicate the continuation of the religious and cultic pre-exilic community of Israel in the post-exilic community. ${ }^{22}$ By creating an archetype in the common original past connected with Sinai the incomparability of Israel, as a nation related to the incomparable God, has been also pointed out and underlined.

\section{Deut 33:2 as a reflection of the nature of the final Pentateuch redaction}

After the short interpretation of the biblical theme of Sinai, we may again ask why the mention of "YHWH from Sinai" was inserted in Deut 33:2? A hint as to the answer of this question can be found in other utterances of the Hebrew Bible.

21 Cf. and see more e.g. W. Oswald, Lawgiving at the Mountain of God, p. 169-170; D. Markl, Sinai, p. 23-26; J. Baden, What Was the Sin of the Golden Calf?; M.B. Hundley, What Is the Golden Calf?, p. 559-579.

22 Cf. and see more e.g. J.K. Hoffmeier, Ancient Israel in Sinai, p. 193-222; W. Oswald, Lawgiving at the Mountain, p. 178-181.186-188; H. Utzschneider, Tabernacle, p. 294-299; D. Markl, Sinai, p. 26; D. Markl, The Wilderness, p. 227-251 (esp. 231-234.241-245); A. Laato, The Origin of Israelite Zion Theology, p. 35-37.276-282. 
There are texts, that mention the mountain in connection with the Israelites and their God YHWH, except those that directly refer to Israel's exodus from Egypt or YHWHs theophany. For example, 1 Kings 20 describes the military conflict between Ahab, king of Israel, and Ben-Hadad, king of Aram. After a battle won by Ahab, the servants of Ben-Hadad told their king about the Israelites: "Their gods are gods of the mountains (אלהי הרים אלהיהם); therefore they were stronger than we..." (1 Kings 20:23). Before the next battle, a prophet said to Ahab: "Because the Arameans have said, YHWH is a god of the mountains (אלהי הרים יהוה) and not a god of the valleys; therefore will I deliver all this great multitude into your hand, and you shall know that I am YHWH" (1 Kings 20:28). According to this announcement, the Israelites defeated the Arameans again (1 Kings 20:29-30). The term "god of the mountains", referred to YHWH in this description, draws attention. Why is it put in the mouth of the Arameans?

The text of 1 Kings 20, that describes Ahab's conflict with Ben-Hadad (historically it would be the middle 9th century BC), shows traces of editorial work. Verses 20-25 and 28, with the term "god of the mountains," are most probably a post-exilic redactional interpolation. ${ }^{23}$

In the narrated time, if the Arameans call God of the Israelites the "god of mountains", then we can suppose that (1) they referred the idea of the connection of an important and great god with a mountain, which was known in ancient tradition, to the God of the Israelites, or (2) they knew the tradition of YHWH as God associated with Synaj /Horeb or Seir, or already with Zion /Jerusalem, or (3) they said so because they were defeated in the mountains of Samaria. War experience in the field of tactics would then suggest fighting on the plain.

In the perspective of the post-exilic redactor, whereas, the term "god of mountains" - at least in this text - is not related to any specific mountain or region (Sinai, Samaria), but it is a general definition. ${ }^{24}$ The author of the statement referred to a known tradition / concept about the relationship of God YHWH with the mountain. The addressees of these words, the post-exilic society of the sons of Jacob, had problems with its identity as God's people. It was certainly the relation with the Samaritans, the status of Ebal and Gerizim, as well as the status of the northern regions of Israel, where the battles of Ahab with

23 The Persian period is indicated, for example, by the term (governor) and mention of Ahab's removal of kings and appointment of governors. So e.g. W. Thiel, Könige, p. 402-404. On the history of the formation of 1-2 Kings see e.g. E.A. Knauf, 1 Könige 1-14, p. 89-98.

24 Cf. W. Thiel, Könige, p. 398. 
Ben-Hadad took place. ${ }^{25}$ It is plausible, therefore, that the redactional addition to 1 Kings 20, in which the statement of YHWH as "God of the mountains" (1 Kings 20:23.28) is put in the mouth of the Arameans, could be then a call to the Judeans not to limit God's presence and activity to their mountain /their mountains and to abandon the tendency of separateness from those who recognized YHWH as "god of the mountains" but according to their concept. For whom YHWH could be „the god of the mountain of the world”, according to the Mesopotamian and Canaanite images. ${ }^{26}$ So, the post-exilic redactional addition to 1 Kings 20 with the words about YHWH as "God of the mountains” appears as a result of a revision of the existing text in a perspective, which universalizes both the scope of God's action and the recipients of his benefits - his blessings.

In turn, the older version of the text of 1 Kings 20 seems to be accompanied by the concept of the distinctness of the Israelites and their certain exclusivism, which we know from some deuteronomistic and priestly fragments (cf. e.g. Lev 20:22-26; Deut 7). That is, why Ahab after his victory was punished for saving the life of Ben-Hadad and for making a covenant with him (1 Kings $20: 31-43) .^{27}$

Let us now return to our main text from the Deuteronomy. According to the last words of the first hymnic stanza, YHWH „was king in Jeshurun, when the heads of the people were gathered, the tribes of Israel together" (Deut 33:5). In this statement, one sees a reference to the first sentence of Josh 24, which says that „Joshua gathered all the tribes of Israel to Shechem” (Josh 24:1). A wide range of researchers sees Josh 24 as a conclusion of a comprehensive Hexateuchal redaction..$^{28}$ So in Deut 33:5, at the end of the Pentateuch - with

25 See e.g. W. Thiel, Könige, p. 410-411.

26 The evidence of the adaptation of the Mesopotamian-Canaanite concept of the relationship between god and mountain by the followers of YHWH we find in the DemoticAramaic Papyrus Amherst 63. In column 12, in verses 11-19, there is a request to God for help from Zaphon (v. 13). The term „Zaphon” does not mean the mountain near Ugarit (Gebel al-Aqra',), the seat of the god Baal, but a mountain of gods par excellence, a mountain associated with God and sanctified by his presence. Cf. and see more about the nature of this papyrus and the meaning of its content e.g. R.C. Steiner, The Aramaic Text in Demotic Script, 309-327; M. Rösel, Israels Psalmen in Ägypten?, p. 81-99; K. van der Toorn, Psalm 20 , p. 244-259.

27 On the reason for the punishment for Ahab as a failure to comply with the war hēem, that was prescribed by law (Deut $7: 2 ; 13: 16 ; 20: 17$ ), and the interpretation of that mentioned event see e.g. J.J. Bimson, 1 and 2 Kings, s. 360; S.J. de Vries, 1 Kings, p. 251; A.H. Konkel, 1 \& 2 Kings, p. 327; R.D. Patterson, H.J. Austel, 1 and 2 Kings, p. 792; W.H. Barnes, 1-2 Kings, p. 174.

28 See e.g. T. Römer, Israels Väter, p. 320-329; R.D. Nelson, Joshua, p. 268-269; E. Otto, Das Deuteronomium im Pentateuch; T. Römer, M. Z. Brettler, Deuteronomy 34, 401-419; 
the last speech of Moses, we have a content element taken from the end of the Hexateuch - with the last speech of Joshua. The Joshua speech in Josh 24 opens with an outline of the YHWH-led history of the Israelites, ranging from Abraham to the occupation of the land Canaan (24:2-13). In this outline of Israel's history, however, there is no mention of the theophany at Sinai, of the covenant and the gift of the Law. So, what, according to the hymnical text of Deut 33, is fundamental to Israel's history and determines its incomparability, is absent in Josh 24.

The absence of the Sinai theme can be interpreted as a sign of tendencies of universalizing both the expanse of YHWH's presence and activity and the recipients of his benefits. In the post-exilic period, these tendencies had to compete with the trends of distinctiveness and exclusivism, which were familiar with the image of Zion, as the mountain of God and the continuation of Sinai. Not to mention Sinai in Josh 24 would be an element of the language of integration (of all Israel) that characterizes Josh 24 and the postulated redaction of the Hexateuch. $^{29}$

A reflection of the universalizing tendencies can also be seen in some statements in Deut 33:6-25. The authors /editors of this text corrected Jacob's blessing from Gen 49, for example, diminishing the supremacy and significance of Judah in favour of the other tribes from central and northern Israel and Transjordan. So, the lion motif was transferred from Judah (Gen 49:9) to Gad and Dan (Deut 33:20.22).$^{30}$ There are no blessing words related to Judah in the text, but a request to YHWH to bring Judah in to his people (Deut 33:7), in which we may see the intention of greater integration of Judah with the other tribes of Israel. ${ }^{31}$ Moreover, Joseph received a special position and distinction in the blessing of Moses (Deut 33:13-17). This is indicated, inter alia, by the fact that the blessing of Joseph's land, which also included the region of Samaria, is connected to a burning bush (סנה, Deut 33:16), which should be understood as

T. Römer, Das doppelte Ende des Josuabuches, p. 523-548; D.M. Carr, The Formation of the Hebrew Bible, p. 273-275. More see e.g. T. Römer, The Problem of the Hexateuch, p. 813-827; T. Römer, The Date, Composition and Function, p. 203-216; J.J. Krause, Hexateuchal Redaction in Joshua, p. 181-202; R. Albertz, The Recent Discussion, p. 65-92.

29 The integration goal can be seen in highlighting the common history led by the one God YHWH and in calling to trust him. See e.g. G. Szamocki, Język integracji narodowej, p. 15-26; T. Römer, T., The Date, Composition and Function, p. 209-210.

30 See the comment of E. Otto, Deuteronomium 12 - 34, p. 2233-2235.

31 Wyrażenie אל־עמו תביאנו może się odnosić do całego ludu Izraela. Cf. J.H. Tigay, Deuteronomy, p. 323. 
a reference to the motif of the mountain of God and Horeb /Sinai. ${ }^{32}$ This reference is used to underline that the Land of Joseph is also part of the Promised Land. So, in Deut 33:16 we may see part of the corrective complement of Gen 49 , as well as a reflection of universalizing tendencies, which were then corrected by the statements in hymnical text of Deut 33:2-5.26-29.

Deut 33:2-5.26-29, as a later text compared to Gen 49 and Josh 24, represents a trend that emphasizes the national and religious uniqueness and distinctness of the sons of Israel, a kind of exclusivism that is noticed in the materials associated with the pentateuchal redaction. In this conception, the summoning of Sinai, as a mountain of theophany, of the covenant and the receiving of the Law, had great formative meaning and function in terms of religious and national identity. It underlined, indirectly, the role of Zion and the contact with the Jerusalem temple as an expression of the persistence in their ancestors' tradition and of the cultivation of belonging to YHWH's people.

\section{Conclusion}

The phrase "YHWH came from Sinai" (Deut 33:2), as a late-post-exilic (5th/4th century BC) redactional addition to Deuteronomy, is a testimony to the tendencies expressed by the redactors regarding the concept of the identity of the Israelites as YHWH's people.

The locution emphasizes making the addressees aware of belonging to a community that religiously and nationally is a continuation of the Israelite society of the First Temple. The rooting in the original theophany of YHWH, in the covenant and the gift of the Law, and in the presence and reign of YHWH at Zion, connect these two communities.

The highlighting in Deut 33:2 on YHWH's relationship with Sinai as God's mountain reflects the nature of disputes and debates regarding the identity of the post-exilic community of YHWH's people. On the one hand, it was about persevering in the faith and tradition of their ancestors and maintaining and strengthening the religious-national awareness of uniqueness and distinctiveness, on the other, about being open to the challenges of time and situation by geographical universalization of the presence and activities of $\mathrm{YHWH}$ and ethnic-religious universalization in the scope of cult participants and recipients of God's blessing.

32 It is meaningful in this context that some Samaritan manuscripts instead of סנה have נס. See more e.g. F.M. Cross, D.N. Freedman, The Blessing of Moses, p. 206; R. Tournay, Le nom du 'Buisson ardent', p. 410-413. 
The sentence "YHWH came from Sinai" in Deut 33:2 can be attributed to the authors of the Pentateuch revision from the late-Persian or even Hellenistic period, for whom the universalizing tendencies did not serve the sanctity of the sons of Israel and did not help to preserve national and religious incomparability and distinctiveness.

\section{References}

Albertz R., The Recent Discussion on the Formation of the Pentateuch/Hexateuch, Hebrew Studies 59 (2018), p. 65-92.

Baden J., What Was the Sin of the Golden Calf?, in: TheThora.com. A Historical and Contextual Approach (https://thetorah.com/what-was-the-sin-of-the-goldencalf/ [22.07.2019]).

Barnes W.H., 1-2 Kings, Carol Stream 2012.

Bergey R., The Song of Moses (Deuteronomy 32:1-43) and Isaianic Prophecies: A Case of Early Intertextuality?, Journal for the Study of the Old Testament 28/1 (2003), p. 33-54.

Beyerle S., Der Mosesegen im Deuteronomium: Eine text-, kompositions- und formkritische Studie zu Deuteronomium 33, Berlin 1997.

Bimson J.J., 1 and 2 Kings, Downers Grove 1994.

Braulik G., Deuteronomium II: 16,18 - 34,12, Würzburg 1992.

Brown F., Driver S.R., Briggs C.A., The Brown-Driver-Briggs Hebrew and English Lexicon with Appendix Containing the Biblical Aramaic, Peabody1997 (repr. from 1906).

Carr D.M., The Formation of the Hebrew Bible. A New Reconstruction, Oxford 2011.

Cassuto U., Biblical and Oriental Studies. 1: Bible, Jerusalem 1973.

Christensen D.L., Deuteronomy 21:10-34:12, Grand Rapids 2002.

Cross F.M., Freedman D. N., The Blessing of Moses, Journal of Biblical Literature 67/3 (1948), p. 191-210.

De Vries S.J., 1 Kings, Grand Rapids 2003.

Dillmann A., Die Bücher Numeri, Deuteronomium und Josua, Leipzig 1886.

Fabry H.-J., Habakuk, Obadja, Freiburg 2018.

Gaster T.H., An Ancient Eulogy of Israel: Deuteronomy 33:3-5,26-29, Journal of Biblical Literature 66/1 (1947), p. 53-62.

Graf K.H., Der Segen Mose's (Deuteronomium c. XXXIII.), Leipzig 1857.

Gray J., A Cantata of the Autumn Festival: Psalm LXVIII, Journal of Semitic Studies 22/1 (1977), p. 2-26.

Groß W., Richter, Freiburg 2009.

Gunneweg A.H.J., Über den Sitz im Leben der Sog. Stammessprüche (Gen 49 Dtn 33 Jdc 5), Zeitschrift für die Alttestamentliche Wissenschaft 76/3 (1964), p. 245-555.

Hempel J., Die Schichten des Deuteronomiums. Ein Beitrag zur israelitischen Literaturund Rechtsgeschichte, Leipzig 1914. 
Hoffmeier J.K., Ancient Israel in Sinai. The Evidence for the Authenticity of the Wilderness Tradition, Oxford - New York 2005.

Hossfeld F.-L., Psalm 68, in: Psalmen 51-100, F.-L. Hossfeld, E. Zenger (eds.), Freiburg 2000, p. 242-259.

Hundley M.B., What Is the Golden Calf?, The Catholic Biblical Quarterly 79/4 (2017), p. 559-579.

Jacobovici S., Mount Sinai Has Been Located, The Jerusalem Post, September 25, 2013.

Jeansonne S.P., Jeshurun, in: The Anchor Yale Bible Dictionary, Vol. 3, D.N. Freedman (ed.), New York 1992, p. 771-772.

Jenni E., Qœedœem, Vorzeit, in: Theologisches Handwörterbuch zum Alten Testament, Bd. II, E. Jenni, C. Westermann (eds.), Gütersloh 1993, p. 587-589.

Jeremias J., Das Königtum Gottes in den Psalmen. Israels Begegnung mit dem kanaanäischen Mythos in den Jahwe-König-Psalmen, Göttingen 1987.

Knauf E.A., 1 Könige 1-14, Freiburg 2016.

Knohl I., Psalm 68: Structure, Composition and Geography, Journal of Hebrew Scriptures 12 (2012), p. 1-21.

Koch K., Qädädem. Heilsgeschichte als mythische Urzeit im Alten (und Neuen) Testament, in: Vernunft des Glaubens. Wissenschaftliche Theologie und kirchliche Lehre. Festschrift zum 60. Geburtstag von Wolfhart Pannenberg, J. Rohls, G. Wenz (eds.), Göttingen 1988, 253-288.

Konkel A.H., 1 \& 2 Kings, Grand Rapids 2006.

Koosed J.L., Jeshurun, in: The New Interpreter's Dictionary of the Bible, Vol. 3, K.D. Sakenfeld et al. (eds.), Nashville, Tennessee 2008, p. 261.

Krause J.J., Hexateuchal Redaction in Joshua, Hebrew Bible and Ancient Israel 6 (2017), p. 181-202.

Kronholm T., Qøedæem, in: Theologisches Wörterbuch zum Alten Testament, Bd. 6, G.J. Botterweck et al. (eds.), Stuttgart 1989, p. 1163-1169.

Kuenen A., Historisch-kritische Einleitung in die Bücher des Alten Testaments hinsichtlich ihrer Entstehung und Sammlung. I/1: Die Entstehung des Hexateuch, Leipzig 1887.

Laato A., The Origin of Israelite Zion Theology, London 2018.

Leuenberger M., Jhwhs Herkunft aus dem Süden. Archäologische Befunde - biblische Überlieferungen - historische Korrelationen, Zeitschrift für die alttestamentliche Wissenschaft 122/1 (2010), p. 1-19.

Leuenberger M., Segen und Segenstheologien im alten Israel. Untersuchungen zu ihren religions- und theologiegeschichtlichen Konstellationen und Transformationen, Zurich 2008.

Levin C., Das Alter des Deboralieds, in: C. Levin, Fortschreibungen. Gesammelte Studien zum Alten Testament, Berlin 2003, p. 124-141.

Levin C., Das vorstaatliche Israel, in: C. Levin, Fortschreibungen. Gesammelte Studien zum Alten Testament, Berlin 2003, p. 142-157.

Lindars B., Judges 1-5. A New Translation and Commentary, Edinburgh 1995.

Markl D., Hab 3 in intertextueller und kontextueller Sicht, Biblica 85/1 (2004), p. 99-108. 
Markl D., Sinai: The Origin of Holinexss and Revelation in Exodus, Deuteronomy, the Temple Scroll, and Jubilees, in: Holy Places in Biblical and Extrabiblical Traditions. Proceedings of the Bonn-Leiden-Oxford Colloquium on Biblical Studies, J. Flebbe (ed.), Bonn 2016, p. 23-43.

Markl D., The Wilderness Sanctuary as the Archetype of Continuity between the Pre-and the Postexilic Temples of Jerusalem, in: The Fall of Jerusalem and the Rise of the Torah, P. Dubovský, D. Markl, J.P. Sonnet (eds.), Tübingen 2016, p. 227-251.

Mayfield T., The Accounts of Deborah (Judges 4-5) in Recent Research, Currents in Biblical Research 7/3 (2009), p. 306-335.

Mendenhall G.E., Jeshurun, in: The Interpreter's Dictionary of the Bible. Illustrated Encyclopedia, Vol. 2, G.A. Butterick et al. (eds.), New York 1962, 868.

Miller P.D., Two Critical Notes on Psalm 68 and Deuteronomy 33, The Harvard Theological Review 57/3 (1964), p. 240-243.

Mowinckel S., Der achtundsechzigste Psalm, Oslo 1953.

Mulder M.J., J'šurûn, in: Theologisches Wörterbuch zum Alten Testament, Bd. 3, G.J. Botterweck et al. (eds.), Stuttgart 1982, p. 1070-1075.

Neef H.-D., Deboraerzählung und Deboralied. Studien zu Jdc 4,1-5,31, Neukirchen-Vluyn 2002.

Nelson R.D., Joshua. A Commentary, Louisville, Kentucky 1997.

Nilsen T.D., The Origins of Deuteronomy 32. Intertextuality, Memory, Identity, New York 2018.

Oswald W., Lawgiving at the Mountain of God (Exodus 19-24), in: The book of Exodus. Composition, Reception, and Interpretation, T.B. Dozeman, C.A. Evans, J.N. Lohr (eds.), Leiden - Boston 2014, p. 169-192.

Oswald W., Sinai, in: Das wissenschaftliche Bibellexikon im Internet (WiBiLex), Deutsche Bibelgesellschaft, 2018, p. 1-13 (http://www.bibelwissenschaft.de/stichwort/28875/ [19.07.2019]).

Otto E., Deuteronomium 12-34. Zweiter Teilband: 23,16 - 34,12, Freiburg 2017.

Otto E., Das Deuteronomium im Pentateuch und Hexateuch. Studien zur Literaturgeschichte von Pentateuch und Hexateuch im Lichte des Deuteronomiumrahmens, Tübingen 2000.

Patterson R.D., Austel H.J., 1 and 2 Kings, in: 1 Samuel - 2 Kings, T. Longman III, D.E. Garland (eds.), Grand Rapids 2009, p. 615-954.

Perlitt L., Sinai und Horeb, in: Beiträge zur alttestamentlichen Theologie. Festschrift für Walther Zimmerli zum 70. Geburtstag, H. Donner, R. Hanhart, R. Smend (eds.), Göttingen 1977, p. 302-322.

Pfeiffer H., Jahwes Kommen von Süden: Jdc 5, Hab 3, Dtn 33 und Ps 68 in ihrem literaturund theologiegeschichtlichen Umfeld, Göttingen 2005.

Pfeiffer H., Mosesegen, in Das wissenschaftliche Bibellexikon im Internet (WiBiLex), Deutsche Bibelgesellschaft, 2007, p. 1-10 (https://www.bibelwissenschaft.de/ stichwort/28093/ [13.07.2019]).

Puukko A.F., Das Deuteronomium. Eine literarkritische Untersuchung, Leipzig 1910.

Ravasi G., Il Libro del Salmi. Commento e attualizzazione, vol. II (51-100), Bologna 1996. 
Reuss E., Die Geschichte der Heiligen Schriften Alten Testaments, Braunschweig 1890.

Rogers C.L., qädim, in: New International Dictionary of Old Testament Theology \& Exegesis, Vol. 3., W.A. VanGemeren (ed.), Michigan 1997, p. 868-870.

Römer T., The Date, Composition and Function of Joshua 24 in Recent Research. A Response to Joachim J. Krause, Cynthia Edenburg, and Konrad Schmid, Hebrew Bible and Ancient Israel 6 (2017), p. 203-216.

Römer T., Das doppelte Ende des Josuabuches: einige Anmerkungen zur aktuellen Diskussion um „deuteronomistisches Geschichtswerk" und «Hexateuch", Zeitschrift für die alttestamentliche Wissenschaft 118/4 (2006), p. 523-548.

Römer T., Israels Väter. Untersuchungen zur Väterthematik im Deuteronomium und in der deuteronomistischen Tradition, Göttingen 1990.

Römer T., Der Mosesegen im Deuteronomium: Eine text-, kompositions- und formkritische Studie zu Deuteronomium 33 by Stefan Beyerle (Review), Journal of Biblical Literature 120/2 (2001), p. 354-356.

Römer T., Brettler M.Z., Deuteronomy 34 and the Case for a Persian Hexateuch, Journal of Biblical Literature 119/3 (2000), p. 401-419.

Rösel M., Israels Psalmen in Ägypten? Papyrus Amherst 63 und die Psalmen XX und LXXV, Vetus Testamentum 50/1 (2000), p. 81-99.

Shanks H., Where is Mount Sinai? The Case for Har Karkom and the Case for Saudi Arabia, Biblical Archaeology Review 40/2 (2014), p. 30-41.

Steiner R.C., The Aramaic Text in Demotic Script (1.99), in: The Context of Scripture. Vol. 1: Canonical Compositions from the Biblical World, W. Hallo (ed.), Leiden 1997, 309-327.

Sussman S., Psalm 68: Echoes of the Song of Deborah, Jewish Bible Quarterly 40/4 (2012), p. 238-240.

Szamocki G., Język integracji narodowej w Joz 24,1-24, Studia Gdańskie 31 (2012), p. 15-26.

Tate M.E., Psalms 51-100, Grand Rapids 1990.

Thiel W., Könige, Neukirchen-Vluyn 2012.

Thiessen M., The Form and Function of the Song of Moses (Deuteronomy 32:1-43), Journal of Biblical Literature 123/3 (2004), p. 401-424.

Tigay J.H., Deuteronomy, Philadelphia 1996.

Timm S., „Gott kommt von Teman, der Heilige vom Berg Paran“ (Habakuk 3:3) - und archäologisch Neues aus dem äußersten Süden (Tell el-Meharret), in: „Gott kommt von Teman ...." Kleine Schriften zur Geschichte Israels und Syrien-Palästinas, C. Bender, M. Pietsch (eds.), Münster 2004, p. 199-218.

Toorn K. van der, Psalm 20 and Amherst Papyrus 63, XII, 11-19: A Case Study of a Text in Transit, in: Le-maan Ziony: Essays in Honor of Ziony Zevit, F.E. Greenspahn, G.A. Rendsburg (eds.), Eugene, Oregon 2016, p. 244-259.

Tournay R., Le nom du «Buisson ardent», Vetus Testamentum 7/4 (1957), p. 410-413.

Utzschneider H., Tabernacle, in: The Book of Exodus. Composition, Reception, and Interpretation, T.B. Dozeman, C.A. Evans, J.N. Lohr (eds.), Leiden 2014, p. 267-301.

Waltisberg M.Z., Zum Alter der Sprache des Deboraliedes Ri 5, Zeitschrift für Althebraistik 12/2 (1999), p. 218-232. 
Wiseman D.J., yeshūrûn, in: Theological Wordbook of the Old Testament, Vol. 1, R.L Harris (ed.), Chicago 1980, p. 418.

Woude van der A.S., Erwägungen zum Rahmenpsalm von Deuteronomium 33, in: Studies in Deuteronomy in honour of C.J. Labuschagne on the occasion of his 65th birthday, F. García Martínez et al. (eds.), Leiden 1994, p. 281-288. 